\title{
A união entre Brasil e Argentina \\ no desenvolvimentismo (1958-1962)
}

Brazil and Argentina united in developmentalism (1958-1962)

Iuri Cavlak ${ }^{1}$

Resumo: Neste artigo, tentamos demonstrar que o período de maior aproximação diplomática da história do relacionamento do Brasil e da Argentina ocorreu no contexto desenvolvimentista, na virada dos anos 1950 para os anos 1960. Tendo como referência o Arquivo de Arturo Frondizi, recentemente aberto à pesquisa, o Arquivo do Ministério das Relações Exteriores, Comércio e Culto da Argentina, o Arquivo do Ministério das Relações Exteriores do Brasil e bibliografia sobre o tema, nosso trabalho recoloca a problemática da integração sobre bases documentais novas.

Palavras-chave: diplomacia, integração, Brasil, Argentina, Arquivo de Arturo Frondizi.
Abstract: This paper tries to show that, in terms of diplomacy, Brazil and Argentina were never as close as during developmentalism, at the end of the 1950's and beginning of the 1960's. Using as reference Arturo Frondizi Archival Fonds, newly open to researchers, Argentinian Ministry of Foreign Affairs Archives, Brazilian Ministry of Foreign Affairs Archives and bibliography on the subject, this work restates the question about integration using new documental evidence.

Keywords: diplomacy, integration; Brazil, Argentina, Arturo Frondizi Archival Fonds.

\section{Introdução}

A história das relações diplomáticas entre Brasil e Argentina vem recebendo muitas contribuições nos últimos anos, motivadas talvez pela

\footnotetext{
${ }^{1}$ Mestre em História pela Universidade Estadual Paulista (UNESP - Assis); doutorando pela mesma instituição; pesquisador bolsista do CNPq. E-mail para contato: iuricavlak@yahoo.com.br
}

Fronteiras: Revista Catarinense de História, Florianópolis, n.17, p.189-210, 2009. 
problemática contemporânea do Mercosul. Com a liberação de documentos diplomáticos inéditos, esses estudos adquirem qualidade extra, proporcionando novas reflexões e informações mais detalhadas. $\mathrm{Na}$ dificuldade da montagem do mercado comum hoje, procuram-se as conjunturas históricas em que semelhantes condições vigoraram, até para "se aprender com o passado".

Neste artigo, trabalhamos com a hipótese de que a maior integração da história das relações entre Brasil e Argentina ocorreu no contexto do desenvolvimentismo dos governos de Juscelino Kubitschek e Arturo Frondizi. Através das fontes do Itamaraty e da documentação recémdisponibilizada da Chancelaria argentina, percebemos o quão longe chegou a união diplomática entre os maiores países da América do Sul, ao ponto de se iniciar a montagem de uma zona de livre comércio, a primeira entre países subdesenvolvidos. A nosso juízo, a Operação Pan-Americana - OPA, lançada em 1958, a criação da Associação Latino-Americana de Livre Comércio - ALALC, em 1960, e os encontros presidenciais em Uruguaiana, em abril de 1961, significaram, dentre outras coisas, a formação de um eixo sul-americano de oposição aos Estados Unidos. O conteúdo do arquivo pessoal de Arturo Frondizi, disponível na Biblioteca Nacional de Buenos Aires, vem confirmando nossas reflexões neste sentido.

No Brasil, depois do suicídio de Vargas, as forças políticas ligadas ao capital internacional e à agroexportação tenderam a se recompor. Porém, a aliança PSD-PTB novamente saiu vitoriosa nas urnas, no começo de outubro de 1955. Com o governo de JK, a industrialização brasileira alcançou um ponto de não retorno, ou seja, a economia não podia mais conviver com a supremacia dos interesses agrários, senão compartilhar os lucros advindos desse setor para a construção de mais indústrias. O processo de substituição de importações, iniciado após a crise de 1929, criou um parque industrial que necessitava da participação do Estado, ora com financiamento, ora com a criação direta de novas indústrias de base. Foi visando justamente esta política econômica que Kubitschek se elegeu, objetivando também a participação do capital externo para tal fim, uma vez que a poupança nacional e o Estado brasileiro na época não tinham como arcar sozinhos com uma tarefa de tal magnitude. Como no contexto do segundo governo de Vargas, o Brasil pleiteou a ajuda dos Estados Unidos, que novamente lhe foi negada, através de evasivas e tergiversações. Tentouse a colaboração com países da Europa, resultando, sobretudo, na instalação das primeiras montadoras de automóveis.

Pressionando os Estados Unidos, Kubitschek foi construindo uma política externa regional para unir os países da América do Sul, percebendo 
o momento de desgaste pelo qual passava a maior nação capitalista em relação à opinião pública latino-americana. Depois de 1945, foi irrisória a colaboração econômica norte-americana para o subcontinente, diferentemente da que havia sido feita em relação à Europa. Por conta disso, em junho de 1958, JK lançou a OPA, um conjunto de ideias e práticas diplomáticas pleiteando ajuda financeira dos Estados Unidos, com o corolário da integração dos países da região para combater o subdesenvolvimento. A união com a Argentina seria a melhor maneira de coagir Washington e, no limite, criar um novo polo de desenvolvimento econômico, mais autônomo frente à potência hegemônica. Com efeito,

Era a burguesia industrial que reclamava outro tipo de tratamento. O Brasil queria falar, com maior calor $e$ objetividade, sobre os problemas que dividiam o mundo. Não havia mais lugar para a diplomacia passiva e subserviente do compasso de Washington. "Verifico que no Brasil - e creio que nos demais países do Continente - amadureceu a consciência de que não convém mais formarmos um mero conjunto coral, uma retaguarda incaracterística, um simples fundo de quadro", disse Kubitschek, perante os Embaixadores do Continente, em discurso que os Estados Unidos receberam com reserva. ${ }^{2}$

No que tange à Argentina, o problema era semelhante, pois o peronismo havia industrializado o país à custa das divisas acumuladas no contexto da guerra, necessitando de novos investimentos para evitar o estancamento da produção. Depois de um interregno militar, assumira o poder a União Cívica Radical Intransigente (UCR I), que tinha como líder um intelectual esquerdista, Arturo Frondizi. Os chamados intransigentes formaram uma nova facção no radicalismo, apegados às ideias de integração nacional, desenvolvimento industrial e modernização econômica. $\mathrm{Na}$ política externa, apostaram nos investimentos estrangeiros com forte controle estatal interno, que alocaria os recursos de forma planejada, evitando a sangria de divisas.

$\mathrm{O}$ fato era que nem os Estados Unidos nem a Inglaterra estavam em condições de aportarem capitais na economia platina. O primeiro, pela

\footnotetext{
${ }^{2}$ BANDEIRA, Moniz. Presença dos Estados Unidos no Brasil. Rio de Janeiro: Civilização Brasileira, 1973. p. 382.
} 
competição de mercados e por divergências políticas históricas. O segundo, por estar voltado para suas colônias e para a reconstrução de sua própria economia interna. Impossibilitada de trabalhar conjuntamente com ambos os países, restou para a Argentina um relacionamento de alto perfil com o Brasil, buscando compensar as relações desiguais com os dois países desenvolvidos por uma cooperação estreita com uma nação em nível semelhante de industrialização. Além disso, enquanto a economia brasileira exportava produtos alimentícios de clima tropical e desenvolvia a indústria pesada, a Argentina era especialista na exportação de produtos de clima temperado e nas indústrias leves.

Diante de tal quadro, passava a ser uma necessidade estrutural para a Argentina a aliança com o Brasil, como forma de manutenção de seu desenvolvimento industrial. Entravam para a ordem do dia as tentativas de redefinição no perfil da dependência, ou um novo padrão de inserção mundial para o Cone Sul. A frustrada tentativa de união política e econômica realizada por Vargas e Perón, o chamado Pacto ABC, relegara experiência e capacidade de negociação com os países centrais do sistema. ${ }^{3}$

\section{2. $O$ contexto}

Nos anos 1950, com a Europa voltada quase que totalmente para si mesma, se refazendo dos estragos do último conflito, e os Estados Unidos preocupados com sua hegemonia, a América do Sul acabou relegada para um plano menor na geopolítica mundial, ensejando com isso experiências heterodoxas de política e de gestão econômica. As constantes tentativas das chamadas "reformas estruturais", como o programa de metas de JK e o conjunto de diretrizes industrializantes de Frondizi, foram expressões das inquietudes sul-americanas. O subcontinente, longe demais da URSS, não demonstrava presença significativa de movimentos revolucionários, reforçando a saída desenvolvimentista como alternativa viável para a modernização e a superação do atraso.

No já clássico estudo de Fernando Henrique Cardoso e Enzo Faletto, destacam-se certas condições que impulsionaram os governos reformistas para realizar as mudanças:

\footnotetext{
${ }^{3}$ Sobre o Pacto ABC, consultar: RECZIEGEL, Ana Luiza. O Pacto ABC: as relações BrasilArgentina na década de 50. Passo Fundo, RS: EDIUPF, 1996; CAVLAK, Iuri. Brasil e Argentina na primeira metade dos anos 50: tentativa de um Mercosul avant la lettre. Revista Relações Internacionais no Mundo Atual. Curitiba, n. 6, 2006; CAVLAK, Iuri. A política externa brasileira e a Argentina peronista. São Paulo: Annablume, 2008.
} 
Não se poderia negar que, em princípios da década de 1950, estavam dados alguns dos pressupostos para este novo passo da economia latino-americana. [...] 1) um mercado interno suficiente para o consumo dos produtos industriais, formado desde o século passado pela integração da economia agropecuária ou mineira ao mercado mundial; 2) uma base industrial formada lentamente nos últimos 80 anos, que compreendia indústrias leves de consumo (alimentícias, têxteis etc) e, em certos casos, a produção de alguns bens relacionados com a economia de exportação. 3) uma abundante fonte de divisas constituída pela exploração agropecuária e mineira; 4) fortes estímulos para o crescimento econômico [...] graças ao fortalecimento do setor externo a partir da segunda metade da década de $1950 ; 5)$ a existência de uma taxa satisfatória de formação interna de capitais em alguns países, como, por exemplo, na Argentina. ${ }^{4}$

Diante disso, vários intelectuais passaram a contribuir com sugestões para efetivar estas potencialidades. O grupo mais notório se articulou em torno da CEPAL (Comissão Econômica para a América Latina), órgão das Nações Unidas voltado para o estudo dos problemas do subdesenvolvimento e para a descoberta de soluções para sua superação. Junto com vários pensadores nacionalistas, a CEPAL se tornou uma espécie de munição teórica para as práticas governamentais:

El pensamiento estructuralista, en la visión cepalina de los '50, se fue articulando en torno de una serie de temas, como la crítica de la teoría tradicional del comercio internacional; el alegato a favor de la industrialización; la planificación, como imperativo del desarrollo; la opción por la integración regional; la necesidad de transformaciones estructurales; una visión integral del proceso de desarrollo; y el relieve de la dimensión social del desarrollo. ${ }^{5}$

\footnotetext{
${ }^{4}$ CARDOSO, Fernando Henrique; FALETTO, Enzo. Dependência e desenvolvimento na América Latina. Rio de Janeiro: Zahar Editores, 1975. p. 10-11.

${ }^{5}$ SZTULWARK, Sebastián. El estructuralismo latinoamericano. Buenos Aires: Editora Universidad Nacional de General Sarmiento, 2005. p. 10.
} 
Para o cientista político Alain Rouquié, o reformismo argentino estava ligado diretamente à situação brasileira. Ao menos a cúpula dos radicais intransigentes admitia estar copiando concepções e práticas de seu maior vizinho:

Historicamente el Brasil y la Argentina siempre rivalizaron por la preponderancia en el Cono Sur de América Latina. Los argentinos creyeron siempre en su superioridad de pueblo blanco, de cultura europea, que vive en un clima templado, y esta idea está sólidamente afianzada en la mentalidad nacional. El frondizismo, realista, acepta los hechos: Brasil crece más rápidamente, está en ventaja con respecto a la Argentina para el desarrollo; la experiencia brasileña debe poder servir a la Argentina, porque los dos países tienen que afrontar los mismos problemas. Es una de las ideas fundamentales del frondizismo, al punto que se ha reprochado a sus partidarios el hacer "un elogio desmesurado de la realidad brasileña”. [...] El Brasil es ejemplar en todo. ${ }^{6}$

A produção teórica do desenvolvimentismo argentino constantemente se baseava em autores e autoridades brasileiras, como Hélio Jaguaribe e Juscelino Kubitschek, a ponto de alguns pensadores argentinos acusarem uma "inspiración brasileña" para o frondizismo. Rouquié, depois de analisar algumas passagens de Celso Furtado e Hélio Jaguaribe, conclui:

Es posible ver los encuentros entre la teoría brasileña y la doctrina argentina del capitalismo nacional. Por todas estas razones el Brasil es una referencia fecunda en la ideología frondizista que ve al gran país vecino con tanto mayor simpatía puesto que atribuye los diferendos, que han separado a los dos países, a la diplomacia inglesa. ${ }^{7}$

A união começava a se expressar na esfera intelectual, abarcando importantes pensadores e partidos políticos. A semelhança nos níveis de desenvolvimento de Brasil e Argentina viabilizou a cooperação econômica,

\footnotetext{
${ }^{6}$ ROUQUIÉ, Alain. Radicales y desarrollistas en la Argentina. Buenos Aires: Schapire Editor, 1975. p. 116.

${ }^{7}$ Ibidem, p. 117.
} 
fortalecendo a posição mútua de ambos no cenário mundial. A paridade de condições e coincidência de interesses se caracterizou como um momento especial das relações bilaterais. Secularmente, as duas nações sofreram com o fato de suas diplomacias responderem a forças antagônicas. A começar pela colonização, sendo a Argentina pela Espanha e o Brasil por Portugal, e posteriormente transformados em zonas de influência de potências diferentes - os argentinos, da Inglaterra, e os brasileiros, dos Estados Unidos. Como resultado do desenvolvimento do mercado mundial e das peculiaridades nacionais, a Argentina se desenvolveu de forma muito mais acentuada que o Brasil, entre os anos de 1880 até 1930. De 1930 até início de 1960, o Brasil emparelhou as condições econômicas e militares com seu vizinho para, a partir de 1970 até os dias atuais, ultrapassá-lo e abrir vantagem.

Além disso, em suas relações, conceitos como "Terceiro Mundo", "subdesenvolvimento" e "deterioração dos termos de troca" passaram a constar na documentação diplomática, sempre com o sentido de denunciar a injustiça da divisão internacional do trabalho. Para Miguel Ángel Scenna, os anos de 1950 e início dos de 1960 se caracterizaram por uma espécie de "tomada de consciência nacional" na diplomacia, o que resultou na barganha nacionalista. Daí a necessidade de um ajuste fino ou uma bem sucedida articulação entre política externa e política interna. No Brasil:

[...] esbozó por primera vez en muchos años un afán de individualidad neta y propia, verdaderamente inédita. Alentado por un grupo de notables intelectuales nacionalistas, comienza a forjarse una nueva imagen del Brasil, dueño de sí, desligado del mandato norteamericano, proyectando hacia el naciente Tercer Mundo y en busca de una acción común, coordinada, con los vecinos latinoamericanos de habla española. ${ }^{8}$

$\mathrm{Na}$ Argentina, no caso da administração frondizista:

[...] el flamante gobierno auspiciaba inmejorables relaciones entre Buenos Aires y Brasilia. La política de acercamiento fue rápidamente puesta en práctica por ambas partes, sobre todo a medida que se manifestaba

${ }^{8}$ SCENNA, Miguel Ángel. Argentina-Brasil: cuatro siglos de rivalidad. Buenos Aires: Ediciones La Bastilla, 1975. p. 348. 
el disgusto de Washington con la administración Kubitschek. La nova tónica no seguía los parámetros mitristas de subordinación al Brasil, ni los de Roca o Justo de simple aproximación. Renovaba en cierta forma la línea de Sáenz Peña en busca de un acuerdo permanente de ambas naciones, profundizándolo hasta extremos sin precedentes. ${ }^{9}$

A diplomacia brasileira e a argentina, além de seguirem tradições próprias, faziam parte de um contexto maior. Nesse período, o processo de descolonização e lutas nacionais na África e na Ásia inspirava o nacionalismo na política externa sul-americana. Como afirma Vizentini:

Em abril de 1955, reuniu-se em Bandung, Indonésia, uma conferência de 29 países afro-asiáticos, defendendo a emancipação total dos territórios ainda dependentes, repudiando a Guerra Fria e seus pactos de defesa coletiva patrocinados pelas grandes potências, enfatizando ainda a necessidade de apoio ao desenvolvimento econômico. Em 1961 reuniu-se em Belgrado, Iugoslávia, a I Conferência dos Países Não Alinhados, na qual convergiram a política de Tito na busca de uma Terceira Via nas relações internacionais, o neutralismo e o afro-asiatismo de Bandung. ${ }^{10}$

\section{A formação da Zona de Livre Comércio}

Em 8 de abril de 1958, faltando pouco menos de um mês para assumir a presidência, Arturo Frondizi foi ao Brasil conferenciar com Juscelino Kubitschek. No percurso até Copacabana, onde ficaria hospedada a comitiva argentina, houve fogos de artifício e bandeiras argentinas nas repartições públicas, sendo que uma carreata acompanhou o cortejo. Momentos antes de embarcar para o Brasil, Frondizi afirmou à imprensa: "Iré al Brasil para decir una vez más que todo nos une y que nada nos

\footnotetext{
${ }^{9}$ SCENNA, Miguel Ángel. Argentina-Brasil, op.cit. p. 351.

${ }^{10}$ VIZENTINI, Paulo F. Do nacional-desenvolvimentismo à política externa independente. In: FERREIRA, Jorge; DELGADO, Lucilia (orgs). O Brasil Republicano: o tempo da experiência democrática - da democratização de 1945 ao golpe civil-militar de 1964. Rio de Janeiro: Civilização Brasileira, 2003. v.3, p. 207.
} 
separa", ${ }^{11}$ frase célebre pronunciada pelo presidente argentino Roque Sáens Peña, quando, em 1910, na sua primeira viagem internacional, veio ao Brasil se reunir com Rio Branco no intuito de discutir a construção de uma "hegemonia dual sobre o continente", combatendo o expansionismo norteamericano. $^{12}$

Na primeira conferência de sua viagem, realizada na Associação Brasileira de Imprensa, Frondizi ressaltou que era contrário a uma das principais demandas do Tratado Interamericano de Assistência Recíproca TIAR e da Organização dos Estados Americanos - OEA, "el desarme para Latinoamérica", se dizendo a favor do crescimento do poderio militar do subcontinente. ${ }^{13}$ De acordo com a Embaixada Argentina no Brasil:

Después de la conquista de Montevideo, a la cual sedujo con simpatía cuando tomó contacto con el pueblo, y con inteligencia cuando habló a los gobernantes, Arturo Frondizi acababa de cumplir su primer día de estada en Río, nueva meta a conquistar para la causa de su gran propósito americanista. Río de Janeiro había recibido al huésped argentino con temperatura de bochorno en el ambiente, entusiasmo popular en las calles y satisfacción exultantes en los representantes del gobierno. ${ }^{14}$

A presença de Frondizi no Rio de Janeiro teve que ser encurtada, pois o líder argentino fez questão de conhecer a cidade de São Paulo. No discurso oficial no Itamaraty, afirmou:

Los países de América Latina afrontamos difíciles circunstancias económicas. Padecemos todavía las consecuencias de una estructura basada en la exportación de materias primas, que encuentran un

\footnotetext{
11 Arquivo Arturo Frondizi (Biblioteca Nacional de Buenos Aires): Caja 570, "Viaje a Brasil”. Apuntes diplomáticos (documentação encontrada de forma aleatória na caixa).

12 BANDEIRA, Moniz. Brasil, Argentina e Estados Unidos: da Tríplice Aliança ao Mercosul (1870-2003). Rio de Janeiro: Revan, 2003. p. 125.

13 Arquivo Arturo Frondizi (Biblioteca Nacional de Buenos Aires): Caja 570, "Viaje a Brasil". Apuntes diplomáticos. Naquela época, tanto o TIAR quanto a OEA respondiam diretamente às ordens dos Estados Unidos, que claramente proibia os países sul-americanos de possuírem armamentos de ponta e uma capacidade sustentável de autodefesa.

${ }^{14}$ Ibidem.
} 
mercado mundial cada vez más restringido, al tiempo que las manufacturas de importación son cada vez más costosas. Los precios internacionales se desvalorizan, surgen nuevas competencias, y decae el interés por muchos productos. Ello acarrea déficits crecientes en las balanzas de pagos, descensos del nivel de vida de la población y los consiguientes trastornos sociales e políticos. Este panorama real nos obliga a extraer conclusiones también objetivas. La primera de ellas es que el esquema económico, sobre el cual fueron trazadas las estructuras básicas de nuestros respectivos países, carece de vigencia... Otros continentes están surgiendo con personería propia. Son nuevas demandas y nuevos mercados pero también nuevas fuentes de producción. El progreso ha dejado de ser privilegio de un reducido núcleo de naciones... Progreso significa mejor alimentación, mejor vestido, mejor vivienda, pero significa también cultura superior e técnica avanzada. $^{15}$

Na sequência, assegurou que se tratava de uma época de imensas conquistas tecnológicas, com invenção diária de novos produtos industriais. Para a América Latina se desenvolver, aproveitando suas enormes reservas energéticas de carvão, petróleo e quedas d'água, era necessária a união econômica das nações. No meio do discurso, lançou a proposta para que Brasil e Argentina fundassem a primeira "siderurgia sudamericana". ${ }^{16}$

Podemos llegar a un mercado común, como una manera de producir la expansión de los mercados mediante una adecuada organización del crédito y la asistencia técnica, para desarrollar industrias y estimular exportaciones.... Esta acción debe estimular los factores de progreso y no sólo los específicamente económicos. Servirá para sumar esfuerzos y aprovechar, en cada país, la experiencia adquirida en los otros. Deberá intensificarse el intercambio de técnicos, deberán emprenderse investigaciones conjuntas y deberá pensarse en la creación de institutos

15 Arquivo Arturo Frondizi (Biblioteca Nacional de Buenos Aires): Caja 570, "Viaje a Brasil": "Discurso pronunciado en Rio de Janeiro por el Doctor Arturo Frondizi, el miércoles 9 de abril de 1958". p. 3.

${ }^{16}$ Ibidem, p. 4. 
comunes para estudiosos y investigadores de todos nuestros países. Esa suma de experiencias constituye un capitulo no menos valioso que el capital financiero y muchas veces una iniciativa feliz puede mucho más que una cuantiosa inversión de dinero. La ciencia e la técnica tienen precisamente la virtud de trocar la inteligencia de unos pocos hombres en bienestar y progreso para muchos millones. ${ }^{17}$

A diplomacia argentina, quando da fala de Kubitschek, destacou as palavras do governante brasileiro que davam conta do ineditismo daquele nível de relação. Depois de sumariar, com bastante ênfase, os períodos históricos de aproximação e concórdia entre os dois países, asseverou JK: "Pero hoy hay realmente entre su país y el mío un eslabón más, un entendimiento más profundo, un fervor mayor que en cualquier otro tiempo". Sobre a integração:

No somos más simples países jóvenes que disputan alegremente privilegios de vida fácil y de fácil prosperidad. Sabemos que solo tenemos un único camino para poder ser poderosos y dar estabilidad y seguridad a nuestras naciones: este camino es el de unirnos fuertemente en medidas prácticas y con coraje y no solamente a través de bellas palabras. ${ }^{18}$

Resumindo essa viagem, destacou a diplomacia platina:

Hubo coincidencia total de los primeros mandatarios. Kubitschek lo dijo estas palabras: "Nunca fue tan grande, tan impostergable el deseo de darnos las manos, de caminar juntos, de hacer una sola política en el interés de todos nosotros, los países sudamericanos". ${ }^{19}$

17 Arquivo Arturo Frondizi (Biblioteca Nacional de Buenos Aires): Caja 570, "Viaje a Brasil": "Discurso pronunciado en Rio de Janeiro por el Doctor Arturo Frondizi, el miércoles 9 de abril de 1958 ". p. 5.

${ }_{18}$ Arquivo Arturo Frondizi (Biblioteca Nacional de Buenos Aires): Notas diplomáticas del Brasil (1958). p. 19.

${ }^{19}$ Ibidem. 
As reuniões presidenciais e a troca de ideias permitiram "el resurgimiento de la Argentina como factor importante de cooperación internacional". ${ }^{20}$ Ao chegar em Buenos Aires, a imprensa portenha sabatinou Frondizi. Suas respostas passaram o sentimento de que uma nova etapa nas relações internacionais na região havia começado. ${ }^{21}$

Quando do lançamento da OPA, ainda em 1958, JK enviou uma carta pessoal a Frondizi, explicando o que tinha em mente e pedindo apoio do mesmo. Bastante entusiasmado, Frondizi de pronto respondeu à missiva, agradecendo o cuidado de colocá-lo a par da situação e prometendo irrestrito apoio..$^{22}$ Depois de divulgada essa opinião na imprensa, vários governantes latino-americanos também se pronunciaram a favor do Brasil, sendo o noticiário argentino preenchido por esse assunto. $\mathrm{O}$ embaixador argentino nos Estados Unidos divulgou nota reforçando os argumentos da política externa brasileira, o chanceler colombiano apoiou entusiasticamente Kubitschek e o presidente do Paraguai fez questão de se mostrar solidário e solícito. $^{23}$

Por todo mês de setembro, esteve reunido em Buenos Aires o "Grupo Misto de Integração Industrial Brasil/Argentina", entidade recémcriada que visava coordenar o desenvolvimento dos respectivos parques industriais. Explicando do que se tratava, escreveu a Embaixada brasileira:

I - Os governos dos Estados Unidos do Brasil e da República Argentina estabelecerão um Grupo Misto de Integração Industrial, com as seguintes atribuições: a) promover estudos tendentes a verificar as possibilidades de cooperação entre os diversos setores industriais dos respectivos países; b) propor aos dois Governos as medidas administrativas necessárias para tornar efetiva a referida cooperação.

II - O grupo misto será composto de uma seção brasileira, com sede no Rio de Janeiro, e uma seção argentina, com sede em Buenos Aires. As duas seções - integradas por representantes dos órgãos governamentais competentes e da indústria -

\footnotetext{
${ }^{20}$ Arquivo Arturo Frondizi (Biblioteca Nacional de Buenos Aires): Notas diplomáticas del Brasil (1958). p. 35.

${ }^{21}$ Ibidem, p. 39.

22 Arquivo do Ministério das Relações Exteriores do Brasil. Missões Diplomáticas no Estrangeiro. Buenos Aires. Ofício n. 649, de 24 de junho de 1958.

23 Arquivo do Ministério das Relações Exteriores do Brasil. Missões Diplomáticas no Estrangeiro. Buenos Aires. Ofício n. 668, de 26 de junho de 1958.
} 
funcionarão em caráter permanente em suas respectivas sedes e, quando necessário, realizarão reuniões conjuntas, em uma ou outra capital.

III - Cada seção poderá propor à outra a constituição de grupos de trabalho ad hoc, integrados por industriais brasileiros e argentinos, com o fim de examinar as possibilidades de cooperação de determinadas indústrias de um e outro país.

IV - Os grupos de trabalho apresentarão relatórios às Seções Nacionais do Grupo Misto, as quais recomendarão aos respectivos governos as medidas necessárias para tomar efetiva a referida cooperação. ${ }^{24}$

Neste clima, Frondizi viajou aos Estados Unidos. Era uma visita histórica, em se tratando do primeiro presidente argentino em exercício a ser recebido na Casa Branca. Na conversa com o presidente Kennedy, Frondizi defendeu a diplomacia brasileira. No relato da Embaixada, o presidente argentino, discursando no conselho da OEA em Washington:

Referiu-se [...] ao "Comitê dos 21", e sua reunião nesta capital [Buenos Aires - nota do autor, I.C.], qualificando-o de "instrumento ágil, em cuyas grandes possibilidades cree firmemente el gobierno argentino, para complementar provechosamente las tradicionales estructuras interamericanas". Declarando, a seguir, que a grande missão que incumbe à OEA consiste em contribuir a elevar o nível de crescimento e a formação de capital na América, o Presidente Frondizi afirmou expressamente: "esa és por otra parte la aspiración de progresso, que informa la iniciativa del eminente Presidente del Brasil, señor Kubitsheck, sintetizada en la formulación de la Operación Panamericana, que há merecido el más decidido y sincero apoio de mi país". 25

Juscelino Kubitschek, na ocasião, enviou uma carta ao Ministério das Relações Exteriores e Culto agradecendo as palavras solidárias de

24 Arquivo do Ministério das Relações Exteriores do Brasil. Missões Diplomáticas no Estrangeiro. Buenos Aires. Ofício (número ilegível) de 19 de setembro de 1958.

25 Arquivo do Ministério das Relações Exteriores do Brasil. Missões Diplomáticas no Estrangeiro. Buenos Aires. Ofício n. 46, de 23 de janeiro de 1959. 
Frondizi e ressaltando sua coragem de defender a OPA em "território inimigo", na medida em que os Estados Unidos eram abertamente contrários a esta faceta da política externa brasileira. Nos jornais da época, dizia-se que, em resposta à "Operação Pan-Americana", Washington havia lançado a "Operação Geladeira", visando boicotar a diplomacia sul-americanista. ${ }^{26}$

Não obstante, o grande acontecimento do movimento integracionista ocorreu após a saída de Kubitschek da presidência. A política externa brasileira se encontrava tão bem arquitetada que Jânio Quadros, sucessor de JK e pertencente a um partido opositor, continuou e aprofundou os parâmetros diplomáticos formulados na antiga administração. Assim, foi possível o encontro dos presidentes Arturo Frondizi e Jânio Quadros na cidade gaúcha de Uruguaiana, fronteira com Passo de Los Libres, entre 20 e 23 de abril de 1961. Para Moniz Bandeira:

Efetivamente, o Brasil jamais desenvolvera tão estreita cooperação com a Argentina, em política exterior, como aconteceu ao tempo de Frondizi, com o qual tanto Kubitschek quanto Quadros e depois Goulart tiveram maior afinidade e consonância de pontos de vista devido à posição internacional dos dois países a aos seus verdadeiros interesses e destinos nacionais. E esse processo de aproximação e coincidência, iniciado com a OPA, culminara com os Acordos de Uruguaiana, que não só possibilitavam a formação de uma comunidade de interesses no Cone Sul, a partir de sólidas e crescentes relações bilaterais, como constituíam um "multiplicador" da capacidade de negociação dos dois países, na política internacional, contrapondo-se ao tradicional esforço dos EUA no sentido de manter a balcanização da América Latina. ${ }^{27}$

Nos preâmbulos desse encontro, a diplomacia argentina elegeu alguns assuntos principais a serem tratados:

Deberá sostenerse, con toda franqueza, la necesidad de plantear sobre nuevas bases el Comercio Argentino-

\footnotetext{
${ }^{26}$ Arquivo do Ministério das Relações Exteriores do Brasil. Missões Diplomáticas no Estrangeiro. Buenos Aires. Ofício n. 70, de 5 de fevereiro de 1959. Vários recortes de periódicos brasileiros anexados ao ofício.

${ }^{27}$ BANDEIRA, Moniz. Brasil, Argentina, Estados Unidos, op. cit. p. 342-343.
} 
Brasileño. ... El acrecentamiento de los volúmenes actuales de exportaciones y importaciones recíprocas, solo podrá ser considerado sobre la base de la apertura de ambos mercados a las producciones que signifiquen contribución a los procesos de desarrollo económico nacional en los que están empeñados los dos países. En consecuencia, deberá manifestarse con toda claridad al mandatario brasileño que el parque manufacturero paulista podrá contar con la apertura del mercado argentino, en tanto el mercado brasileño se abra para los rumbros nuevos de la producción nacional de nuestro país que registren saldos exportables. Es decir: la Argentina será el mercado eventual, por ejemplo, para el material ferroviario brasileño si el Brasil orientar hacia nuestro país su política de compras en materia de petróleo y derivados, tractores o productos de la metalurgia liviana. Una vez postas las bases de la estructura futura del intercambio podrá encararse la solución del problema del saldo que a favor de nuestro país registra la cuenta convenio. ${ }^{28}$

Com toda pujança econômica, o Brasil apresentava déficit nas relações comerciais com os argentinos, que poderia ser ajustado no próximo encontro. A respeito dos "problemas hemisféricos", afirmava-se:

Por tratarse de problemas que afectan de manera directa a todos los países latinoamericanos y que repercuten inmediatamente en su estructura política y social, resulta inexcusable la necesidad frente a los mismos de una posición que preserve de manera cuidadosa la capacidad de autodeterminación de cada país en función del interés nacional. Si Brasil y Argentina unifican criterios con relación a cada problema que se presente dentro del sistema y ofrecen, en consecuencia, un frente unido, las posibilidades de solución de los mismos aumentarán correlativamente. [...] $\mathrm{Se}$ considera que la significación adquirida por la Argentina y el Brasil impone a ambos países la

${ }^{28}$ Arquivo Arturo Frondizi (Biblioteca Nacional de Buenos Aires). Caja 624: "Uruguaiana". Nota diplomática de 5 de abril de 1961. 
necesidad de aumentar su influencia en los grandes problemas de política internacional. ${ }^{29}$

No que tange ao Tratado de Amizade e Consulta, havia muito otimismo. Assegurou-se que ele:

a) contribuirá a la disipación definitiva de resquemores y rivalidades tradicionales, hoy anacrónicos, ya que, sin perjuicio de que existan todavía intereses encontrados en determinadas regiones, los puntos de coincidencia del Brasil y de la Argentina son hoy muchos más vastos e importantes; b) instrumentará un medio ágil y positivo tendiente a aumentar la capacidad de negociación de los países. El gobierno argentino considera que esta política, rigurosamente nueva, multiplicaría la influencia de los países e indirectamente, de América Latina. ${ }^{30}$

Para as questões mais gerais, prometia-se:

Las bases del Tratado supondrían asimismo información y/o consulta previa sobre: a) cualquier modificación de importancia en la política exterior de Brasil o de la Argentina con referencia a problemas continentales o extracontinentales; b) gestiones comerciales de importancia ante los principales países individualmente considerados (en especial Estados Unidos de América, Unión Soviética, Japón, Gran Bretaña, Francia, Alemania). El acuerdo prevería un régimen de consulta estable y periódico en el nivel presidencial. $^{31}$

Como uma espécie de pano de fundo, Frondizi, Quadros e seus respectivos chanceleres, Diógenes Taboada e Afonso Arinos de Mello e Franco, chegaram a Uruguaiana com intuito de também discutirem formas mais aceitáveis para os demais países do continente, sobretudo os Estados

\footnotetext{
${ }^{29}$ Arquivo Arturo Frondizi (Biblioteca Nacional de Buenos Aires). Caja 624: "Uruguaiana". Nota diplomática de 5 de abril de 1961.

${ }^{30}$ Ibidem.

${ }^{31}$ Ibidem.
} 
Unidos, que pudessem evitar a expulsão de Cuba da OEA. Sofrendo pressões internas dos militares, Frondizi resistia nesse assunto, contagiado por uma espécie de point d'honneur do pensamento diplomático brasileiro: a defesa da autodeterminação e da não intervenção na ilha. ${ }^{32} \mathrm{O}$ presidente brasileiro vinha de um encontro com Fidel Castro.

No aspecto militar, Brasil e Argentina comprometeram-se a retirar as tropas estacionadas em suas fronteiras, decidindo criar um sistema permanente de consulta, a exemplo da esfera política. Um alto oficial do Exército brasileiro deveria ser designado para ficar em Buenos Aires, com a missão de manter contato semanal diretamente com a presidência da República. ${ }^{33}$ Encaminhado o problema militar, outras variáveis foram contempladas. Em linhas gerais, de acordo com Moniz Bandeira:

Quadros e Frondizi acompanharam a elaboração dos textos da Convenção de Amizade e Consulta e da Declaração de Uruguaiana. O primeiro, assinado pelos chanceleres Afonso Arinos de Melo Franco, do Brasil, e Diógenes Taboada, da Argentina, instituía um sistema permanente de consultas e informações, defendia maior integração entre a Argentina e o Brasil nos campos econômico, financeiro, judiciário e cultural, prometia legislação para permitir a livre circulação aos nacionais dos dois países e terminava por facultar a outros estados latino-americanos a adesão a este protocolo. A Declaração de Uruguaiana, firmada pelos dois chefes de estado, estabelecia a ação comum do Brasil e da Argentina na solução dos problemas internacionais; a preservação por ambos da democracia e da liberdade em benefício do desenvolvimento nacional de cada um; a repulsa tanto à interferência de poderes extracontinentais na América Latina quanto à intervenção na soberania das nações; a necessidade de ação conjunta continental em defesa da estabilidade política e social dos países da América; por fim, o reconhecimento de que o esforço nacional era inerente ao desenvolvimento, o que implicava a defesa dos recursos básicos. ${ }^{34}$

\footnotetext{
${ }^{32}$ BANDEIRA, Moniz. Brasil, Argentina, Estados Unidos, op. cit. p. 306. Esse encontro de Uruguaiana ocorreu dias após a fracassada invasão na Baía dos Porcos.

${ }^{33}$ Ibidem, p. 308-309.

${ }^{34}$ Ibidem, p. 309-310.
} 
O presidente brasileiro propôs a formação imediata de um movimento neutralista para defender Cuba, dizendo inspirar-se nos países que apoiavam o processo de descolonização na Ásia e na África. Frondizi prometera realizar este intento num futuro próximo. Assim:

Diante do gradual fechamento do mercado europeu e sem perspectiva de aumentar as exportações para o mercado norteamericano, a Argentina começou a exercitar, da mesma forma que o Brasil, uma espécie de neutralismo potencial, sinalizando a possibilidade de evoluir para o neutralismo positivo, tal como praticado pelo Egito, Índia e outros países da África e da Ásia, caso os Estados Unidos não cooperassem com o seu desenvolvimento econômico, como contrapartida à solidariedade no confronto com a URSS. Os acordos de Uruguaiana, alcançados por Quadros e Frondizi em 1961, constituíram a pedra angular dessa variante de neutralismo, uma vez que a aliança com o Brasil propiciava à Argentina o necessário suporte externo para que pudesse ensaiar, com a questão de Cuba, uma política de relativo descomprometimento na guerra fria, mantendo certa independência e equidistância crítica no conflito ideológico e militar entre os EUA e a URSS. ${ }^{35}$

Para Miguel Angel Scenna, o que ocorreu em Uruguaiana foi "uno de los acuerdos más importantes suscriptos por nuestro país en su historia diplomática y aun en la esfera latinoamericana". ${ }^{36}$ Opinião semelhante é a de Juan Archibaldo Lanús: "se logró establecer entre ambos países un tipo de diálogo excepcional para la historia de las relaciones bilaterales". ${ }^{37}$

$\mathrm{Na}$ imprensa, a repercussão foi enorme. No arquivo de Arturo Frondizi, encontram-se centenas de reportagens da época (chegamos a contar cerca de 400), escritas em diferentes jornais argentinos e brasileiros. Os articulistas previam um arco de possibilidades para o futuro, apostando na união total, com a desaparição das fronteiras, a eleição de um governo, moeda e capital comuns. ${ }^{38}$ Como afirma Lanús, os presidentes "tenían

\footnotetext{
${ }^{35}$ BANDEIRA, Moniz. Brasil, Argentina, Estados Unidos, op. cit. p.334.

${ }^{36}$ SCENNA, Argentina-Brasil, op. cit. p. 357.

${ }^{37}$ LANÚS, Juan Archibaldo. De Chapultepec al Beagle: política exterior argentina, 19451980. Buenos Aires: Emecé, 1984. p. 290.

${ }^{38}$ Arquivo Arturo Frondizi (Biblioteca Nacional de Buenos Aires). Cajas 624, 629, 636 e 670. "Uruguaiana".
} 
conciencia de que estaban protagonizando un episodio excepcional en la historia de las relaciones bilaterales entre ambos Estados". ${ }^{39}$ Exemplo de algumas informações fornecidas pela embaixada brasileira a respeito da repercussão em Buenos Aires:

A Embaixada remete, a título informativo, recortes de jornais dessa capital com amplo noticiário, editoriais e comentários publicados na imprensa local. [...] A esse respeito, a Embaixada em Buenos Aires deseja informar a Secretaria de Estado de que, com exceção do incluso editorial hoje publicado por "La Prensa", não poderia ter sido melhor a repercussão na imprensa argentina dos atos assinados pelos dois Chefes de Estado naquele histórico encontro que está fadado, indiscutivelmente, a imprimir novos rumos às relações políticas, econômicas, comerciais e culturais entre o Brasil e a Argentina. ${ }^{40}$

Ainda segundo a missão diplomática brasileira:

Durante dois dias da reunião de Uruguaiana o país esteve com suas atenções voltadas para aquela cidade brasileira, esperava-se com justificada ansiedade o desfecho das conversações mantidas entre os dois Presidentes... Todos os jornais divulgavam com o maior destaque os textos dos documentos firmados pelos dois Chefes de Estado naquela cidade gaúcha: Declaração Conjunta, a Declaração Econômica e o Convênio Cultural. A imprensa em geral (a única exceção foi um editorial aparecido em "La Prensa" contrário a certos termos da Declaração Conjunta) recebeu favoravelmente os acordos assinados em Uruguaiana. Ao regressar de sua entrevista com o Presidente Quadros, o Presidente Frondizi, ainda no aeroporto, declarou o seguinte: "Estou muito satisfeito com a viagem e creio que a mesma significa um passo

${ }^{39}$ LANÚS, De Chapultepec al Beagle, op. cit. p. 292.

40 Arquivo do Ministério das Relações Exteriores do Brasil. Missões Diplomáticas no Estrangeiro. Buenos Aires. Ofício n. 139, de 25 de abril de 1961. 
positivo para o maior entendimento entre os dois povos e para a solidariedade continental". ${ }^{41}$

Para José Luis Beired,

As relações de cooperação entre Brasil e Argentina assumiam, em Uruguaiana, a feição de alternativa tanto à solução revolucionária cubana para a vida política e o desenvolvimento da América Latina, quanto à solução de dominação econômica e ideológica norte-americana, no contexto da guerra fria. ${ }^{42}$

A simetria entre Brasil e Argentina era tão forte que o movimento não sentiu o mínimo abalo com a renúncia de Jânio Quadros. Mesmo com João Goulart, político pertencente a um partido diferente tanto de JK quanto de Quadros, as relações ainda mais se estreitaram:

Frondizi, ao passar em setembro de 1961 pelo Rio de Janeiro, não só reafirmou com o presidente João Goulart os termos da Declaração e do Convênio de Uruguaiana, como convidou o chanceler San Tiago Dantas a visitar a Argentina, a fim de que os entendimentos prosseguissem com o chanceler Miguel Angel Cárcano. ${ }^{43}$

Alguns meses depois, na VIII Reunião de Consulta dos Chanceleres Americanos, em janeiro de 1962, em Punta del Leste, as delegações brasileira e argentina trocaram informações e impressões, decidindo por abster-se de votar a expulsão de Cuba da OEA.

\footnotetext{
41 Arquivo do Ministério das Relações Exteriores do Brasil. Missões Diplomáticas no Estrangeiro. Buenos Aires. Ofício n. 139, de 25 de abril de 1961.

42 BEIRED, José Luis. La experiencia histórica del Brasil y de la Argentina (1955-1964). In: LLADÓS, A.F; TREVERTON, G.F. (org). Perspectivas: Brasil y Argentina. Buenos Aires: Cari, 1999. p. 293-310.

43 CERVO, Amado. Relações Internacionais na América Latina: velhos e novos paradigmas. São Paulo: Saraiva, 2007. p. 165.
} 


\section{O trágico final}

A formação do eixo Brasília-Buenos Aires contagiou a América do Sul, galvanizando o início do funcionamento da ALALC. Fundada oficialmente em fevereiro de 1960, em Montevidéu, após varias reuniões de cúpula, iniciou seu funcionamento efetivo em $1^{\circ}$. de junho de 1961, com a participação de Brasil, Argentina, Chile, México, Paraguai, Peru, Uruguai, Colômbia e Equador.

Dependente do tipo de governo de turno, a ALALC teve um desenvolvimento considerado satisfatório apenas em seus três primeiros anos, isto é, antes que as ditaduras militares se instaurassem em quase todo subcontinente. Levando em conta o período que vai de seu início efetivo, em 1961, até seu final, em 1980, a ALALC obteve 75\% das liberalizações nas taxas das mercadorias dos países membros neste curto período (19611963), sendo os restantes $25 \%$ obtidos nos demais 17 anos. Foram 4.262 produtos em 1962 e 3.333 em 1963. Daí em diante, não se passou de uma média anual de 240 produtos. $^{44}$

Ocorreu que, com o avanço dos movimentos populares no início dos anos 1960, e a cada vez mais cerrada oposição dos Estados Unidos à união do Cone Sul, militares treinados pelos próprios norte-americanos foram instigados a derrubarem os governos eleitos e assumirem o poder em seus respectivos países. Entre 1961 e 1963, somente na América do Sul, sete golpes militares foram desfechados com sucesso. Na Argentina, em março de 1962, uma junta militar derrubou o governo de Frondizi, direcionando de imediato a diplomacia argentina para os Estados Unidos, desfazendo pouco a pouco o movimento integracionista com o Brasil. Em abril de 1964, João Goulart também foi apeado do poder, com nossa diplomacia abandonando os países da região em nome da solidariedade à grande potência do norte, na batalha contra a expansão do comunismo. A ALALC entrou num processo de estancamento e decadência. Nos anos 1960 e 1970, brasileiros e argentinos trocaram a união pela competição econômica.

Assim, no período mais fértil para o mercado comum, quando se questionava a divisão internacional do trabalho, quando Brasil e Argentina detinham paridade no desenvolvimento econômico e militar, quando governos eleitos possuíam estratégias em comum, a tensão da Guerra Fria e

\footnotetext{
${ }^{44}$ SALGADO, Germánico. El Mercado Regional Latinoamericano: el proyecto y la realidad. Revista da CEPAL, Buenos Aires, n.7, abril de 1979. p. 86, 87 e 90.
} 
o conservadorismo de certas elites acabaram com a integração. Por outro lado, por mais que tenham aumentado seu comércio bilateral, as duas nações não lograram a articulação de setores econômicos poderosos ligados a esta empresa, bem como grupos políticos internos que pudessem sustentar a política externa heterodoxa.

Uma oportunidade histórica para desfazer o papel subalterno do continente sul-americano foi perdida. Depois da crise da dívida dos anos 1980 e da ofensiva neoliberal dos anos 1990, o mercado comum do sul vem se mostrando cada vez mais problemático, com seus países envoltos em graves crises econômicas e visíveis assimetrias de poder. Diante disso, a conjuntura desenvolvimentista não deixa de ser lembrada com certo saudosismo e tristeza. 